\title{
\begin{tabular}{ll}
\hline 総 \\
\hline
\end{tabular} \\ 大豆タンパク質の構造と食品物性 \\ 山内文男*
}

\section{Structure and Food Properties of Soybean Proteins}

\author{
Fumio Yamauchi*
}

大豆は古来アジアを中心とした地域の重要なタンパク 質源で, 豆乳, 豆腐や，さらに味噌，獎油，納豆などの 伝統的食品として利用されてきた。近年，米国において 小麦と共に植物タンパク質として，高価な動物性タンパ ク質の混合物，あるいは組立食品の素材として利用され はじめた。わが国においても次第に生産量が増し，とく に200カイリ海域問題もあり魚肉製品にも多く利用され ている11。大豆タンパク質は栄養価も高く：これから予 想される食糧問题解決の重要なタンパク質源として注目 されていることは良く知られている。

伝統的食品の製造法の改善や，品質向上，あるいは更 に高度な合理的利用を行なうには大豆タンパク質の構造 が完全に解明されればより有効である。そしてその構造 に基づいて発現する物性との関連が明らかになれば，よ り広い利用へとつながるであるう。

大豆タンパク質については, 基礎から食品的研究まで 含めると非常に多くの報告がなされている。従って文献 を調べるのに多くの労力を必要とするので, ここでは出 来るだけ多くの文献を，簡単ではあるがなるべく網羅し て紹介したい。

大豆タンパク質の構造についてはすでに成書2) や総 説占 があり，食品的利用についても成書2)や総説4,5)があ りまた構造とその利用からの総説ひー8) がある。これら の中で構造については越山の総説 $(1976)^{8)}$ と食品的物性 については青木の総説 $(1975)^{5}$ が比較的新らしく良くま とまっている。よってここではこれらの総説に載ってい る内容は基本的なことだけにとどめ，これらに含まれて いない報告と，それ以後 1978 年中頃までの報告を中心
にその概要をのベたい。

タンパク質は高分子なので食品的特性としては味や香 りよりる物性が主体を占めているので構造と物性に主体 を置いて述べる。なおこの両者を結びつけるタンパク質 の変性 ${ }^{4,6)}$ という御点から眺めるのも興味ある領域であ るが,この点に関しては他の稿に譲りたい。

大豆タンパク質の構造と物性との関連は次第に明らか になりつつあるが，まだ多くは解明されていない。この 関連性を研究する上で最も障害になり易いのは，これま での食品的試験法で物性を測定する際に多量の試料を必 要とすることである。もちろん量的に調製しやすい粗タ ンパク質画分でも, ある特性が知られ有効な利用に結び つくことはあり得る。しかし核酸やフィチンなどは比較 的強固にタンパク質と結合しており，ある物性にはこれ らの物質が関与していることも考えられるので，厳密に は精製されなくてはならない。超遠心分析やゲル電気泳 動で単一なタンパク質を得るには大変な労力を必要とす る。そこで一方では純度の高いタンパク質を容易に多量 調製する方法の検討と共に，他方なるべく少量の試料で 物性を測定する方法の開発が必要である。よって使用さ れている測定方法の概要についても述べたい。

\section{大豆タンパク質の構造}

(1) 大豆タンパク質の分類2,81

大豆種子中には約 $40 \%$ のタンバク質が合まれ，脱脂 大豆を水抽出すると約 $90 \%$ のタンパク質が抽出される。 これを $\mathrm{pH} 4$ ～5 酸性にするとタンパク質の約 $80 \%$ が 等電点沈澱するので，酸沈揤タンパク質あるいは大豆グ

* 東北大学農学部食糧化学科 ( Department of Food Chemistry, Faculty of Agriculture, Tohoku University, Sendai, Miyagi 
表 1. 大豆タンパク質の分類と組成

\begin{tabular}{|c|c|c|c|c|}
\hline \multicolumn{3}{|c|}{ タンバク劦の程铏 } & \multicolumn{2}{|c|}{ 祖 成 } \\
\hline 沈 & 成分 & 近湖学的成分 & 趣遠心分析14) & 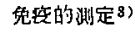 \\
\hline $2 \mathrm{~S}$ & עי & ロ $ロ$ エンダリシニン & $16 \%$ & $15 \%$ \\
\hline $7 \mathrm{~S}$ & 11 & 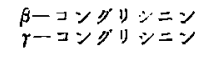 & $\begin{array}{r}41 \\
7\end{array}$ & $\begin{array}{r}27.9 \\
3.0\end{array}$ \\
\hline $11 \mathrm{~S}$ & $"$ & ダリシニン & 31 & 4.0 \\
\hline $15 \mathrm{~S}$ & 11 & - & $\sim 3$ & - \\
\hline
\end{tabular}

ロブリンと呼ばれる。超遠心分析によると，2,7, 11, 15 の4成分にわかれ，免疫学的にはグリシニン, $\alpha-, \beta-, \gamma-$ コングリシニンの 4 成分にかかれる。相互の関係および 含量は表 1 に示した。

このうち大豆グロブリンの主成分は $11 \mathrm{~S}$ (グリシニン) と7S（ $\beta$-コングリシニン）で両者を合わせると大豆グ ロデリンの䄪 $70 \%$ に達するが，両者の比率は品種によ って多少異る。 $7 \mathrm{~S}$ タンパク質成分には $\beta$-コングリシ ニン10)と $\gamma$ ーニングリシニン11が存在するが，免疫学的 差異の他㳙前はイオン強度を低くするとダイマーの

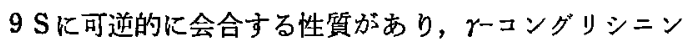
はこの性質がないとされている。大豆タンパク質はイオ 強度や $\mathrm{pH}$ の变化で容易に解離, 会合が起る。イオン 強度 $0.5, \mathrm{pH} 7.6$ の緩衝液は解離，会合が起きないの で標淮緩衝液と呼ばれ，大豆タンぱク質の溶解には広く 用いられてきた。かし最近この条件ではモノマーとダ イマーの混合物であり， $7 \mathrm{~S}$ (以後単に $7 \mathrm{~S}$ は $\beta$ ーコン

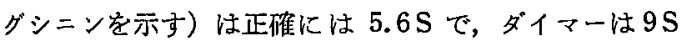
でなく10Sで，完全にモノマーになるにはイオン強度が 0.8 以上でなくてはならないという重要な発見があっ

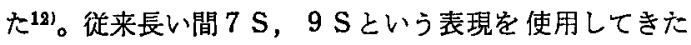
ので急にこれを変えることは混乱する恐れもあるが，い うれはこの名称は考充直すべきであろう。

防ングリシニンは以前から多くの成分からなるので はないかと言われてきたが, 電気泳動的にも3 成分が示 され(18)，さらに DEAE-セフォデックスでこれらのへテロ ジェニティをもつ6種の $\beta$-コングリシニンが分離され

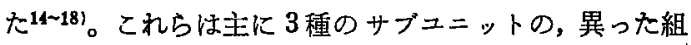
合せからなることが明らかになった はへテロジェニティのない単一なタンパク質とされてい ๖。

大豆登熟中のタンパク質の種類の变化が調べられ初期

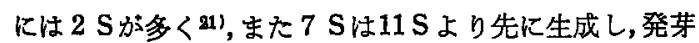
中では11Sから減少しはじめた22)。登熟初期には $1.2 \mathrm{~S}$ の低分子タンパク質が生成するが，これは混在するプロ
テアーゼによって7Sが分解したものに由来した 22 201。 登熟中に現れる $7 \mathrm{~S}, 11 \mathrm{~S}$ は完熟した $7 \mathrm{~S}, 11 \mathrm{~S}$ のザ

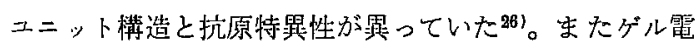
気泳動によって品種の差によるタンパク質の相㒉がみら れた ${ }^{27 ! 。}$

(2) 丁ミノ酸と精組成2,31

主成分である11Sおよび7 Sのアミ／酸含量で，最も 多いのがダルタミン酸とアスパラギン酸の酸性フミノ酸 で，両者が約 $45 \%$ にもなり特に前者が多い。これら酸性 アミノ酸の的半量がアマイド態である。11 Sと7 S 岩比 ベると,トリプトフォン，メチオニン，シスチンの含量 は11Sの方が多い。リジン含量は $7 \mathrm{~S} か ゙$ 多く，含硫了ミ

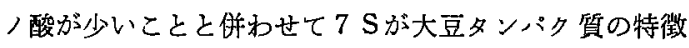
をよく代表している。

1/2シスチンの含量はそのジスルフィド結合 $(S-S$ 結 合）により解離，会合に関与し，物性に大きな影響安む つが，7 Sではその含量が非常に少なく，分子量を18万 とすると 4 モル程度で，かつ SH はもたない。11 Sは分 子量它 35 万とすると 44 モル含京れ，その 2 モルが $\mathrm{SH}$ である28)。これはメルカプトエタノールなどの還元 率が11Sにより鋭敏なことと一致する。

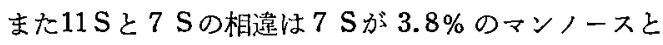
$1.2 \%$ のグルコサミンを含む䌅タンパク質であるが299, $11 \mathrm{~S}$ は糖を含まない301。7 Sの糖部分はフスパラギン酸 のアミドと結合し， 3 種のへテロジェニティをもち， 1 分子中 $5 \sim 6$ 個所で結合している ${ }^{31,82)}$ 。糖の存在は糖之 タンパク質の結合するフフィニティクロマトグラフィー に応用され，糖を公まない11 S と分蜼される。なお ングリシニンも 5 \%の糖を含む糖タンパク質である11。

(3) サブニニット構造

大豆タンベク質はサブュニット構造で出来ているが， $11 \mathrm{~S}$ 法酸性サブュニットと塩基性 サプニニットから成

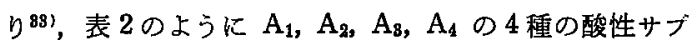
ユニットと $\mathrm{B}_{1}, \mathrm{~B}_{2}, \mathrm{~B}_{8}, \mathrm{~B}_{4}$ の 4 種の塩基性サプユニットか ら成っていることが最近明らかにされた ${ }^{84-871 。 こ れ ら の ~}$ 分子量は酸性サプユニットの方が大きく, 塩基性サブニ ニットの方が小さい。塩基性サプニニットの $\mathrm{N}$ 末端はす ベてグリシンであるが酸性サブニニットはフェニルアラ ニンとロイシン（またはインロイシン）からなる。これ らのサブニニットは酸性サブニニット1個と塩基性サプ ニニット 1 個の 2 個ずつが S-S 結合で 3 種 ( I , II, III)の 中間サブニニットを形成している。これらの中間サブニ ニットが3個集って半量体となりこれが 2 倍となって分 子量36万の11 Sグロブリンを形成している。11Sをトリ 
表 2. 11Sタンパク質のサブユニット粠造

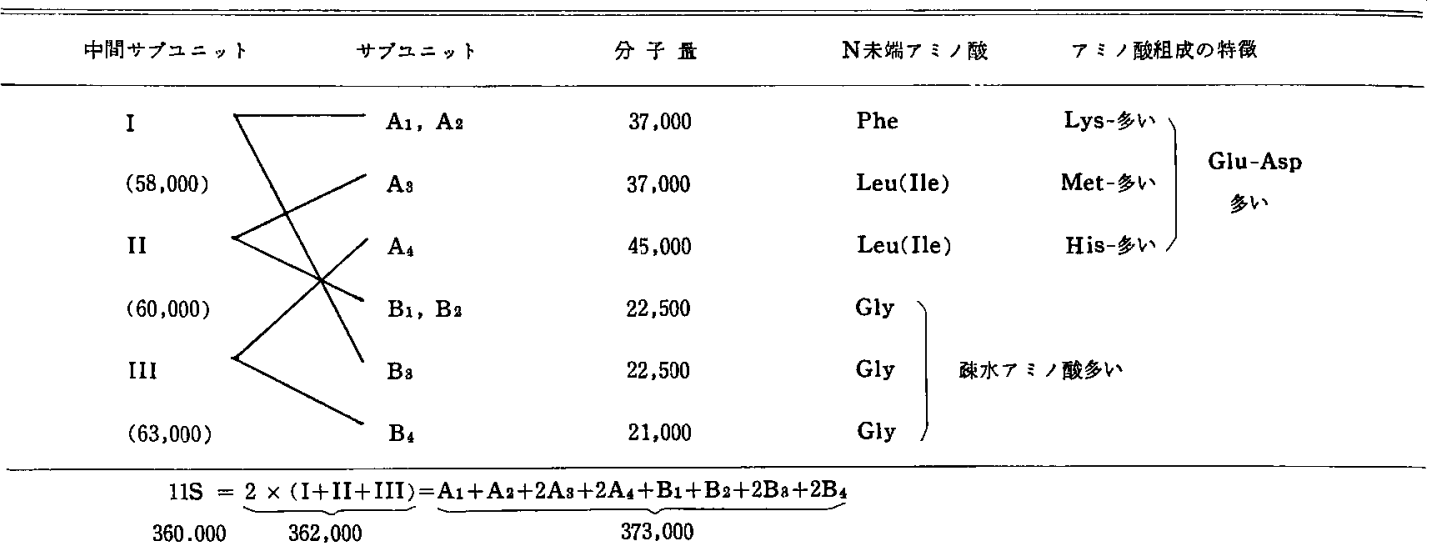

プシンで分解すると, 酸性サブニニットが塩基性サプニ ニットより早い速度で分解される ${ }^{88,89) 。 ま た ト リ フ ゚ シ ン ~}$ で部分分解した消化中間体のサプユニット組成を調ベる。 と $B_{1}, B_{2}, B_{8}$ を含む部分と $B_{4}$ を含む部分にわかれてお り ${ }^{40)}$ ，またイオン強度を变えて分解すると消化生成物む 異っていた41)。

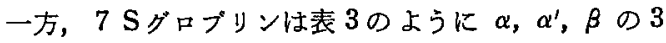
種のサブユニットからなり ${ }^{18,19)}$ ，前述のようにこれらの 組合せによって図 1 のように6 種 $\left(B_{1} \sim B_{6}\right)^{19,201}$ のへテ ロジェニティか出来ている。飯渕らも $\alpha$ と $\beta$ の2種の サプニニットを見出し，3個の一テロジェニティを報告 しているが，この $\alpha$ は前記の $\alpha, \alpha^{\prime}$ の混合物と考えられ

表 3. 7S (

\begin{tabular}{|c|c|c|c|}
\hline サプンニット & 分子量 & N末端フミ，醊 & 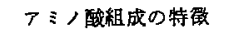 \\
\hline$\alpha$ & 57,000 & Val & 两者は似ているが $\alpha^{\prime}$ は \\
\hline$\alpha^{\prime}$ & 57,000 & Val & His が多以。蹯水フミ， \\
\hline$\beta$ & 43,000 & Leu(Ile) & 酸，Asp が多い。 \\
\hline
\end{tabular}
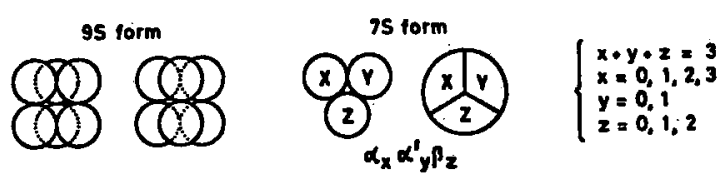

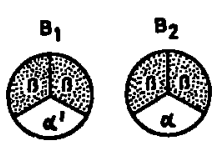

Group A

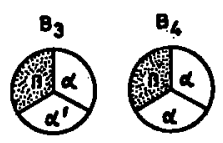

Group $\mathrm{a}$

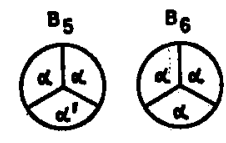

Group C

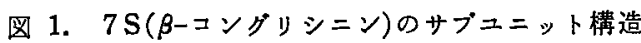

る12)。なお 3 個のサブユニットの組合せがらすると 10個 の一テロジェニティが考えられるが，各サブニニットが 会合して再構成される性質からみると6 個のへテロジェ ニティの存在が妥当と考えられた ${ }^{48 \text { 。 }}$

rーコングリシニンは分子量約 5 万からなる同一のサブ ユニット 3 個からなり $\mathrm{N}$ 末端はイソロイシンであるせ。 ほかにサブユニットの知られているのは $\alpha$ れングリシ ニンの 1 種 $2.8 \mathrm{~S}$ であり分子量 3 万 6 千の 1 本のポリペ プチドからなり，N末端はフスパラギン酸である2。

大豆タンパク質に特有なサブニニットを目印にしたゲ ル電気泳動法が，動物性タンパク質と混合したときの大 豆タンパク質の定性や定量に応用されている45 48,160,182)。 また肉製品中の大豆タンパク質含量を混在する糖の定 量 $^{49)}$ 又はトリプシン消化後のペプチドを目印にしてフミ ノ酸分析機で定量している

(4) 高次構造および電子顕微鏡観察》)

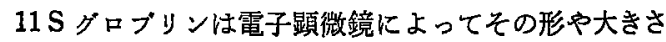
が調べられており，因 2 のように半量体は 6 個のサブユ ニットが中空の円筒状のように連なっていると理解され ており ${ }^{(1)}$ ，これは表 2 の半量体のサプニニット数とる一 致している。しかし電子顕微鏡の解析能がまだ充分でな く，またタンパク質もその環境状態で異るためか，その 形や大きさ汧究者によって多小異る。11Sの分子溶液 論的な物理化学的定数加ら計算すると, 形は長軸 $180 \AA$, 短軸 $22 \AA$ の扁平楕円体で, 水溶液中でも水和はほとん どない。かたい棈造をるつと推定されている52!。

それぞれのサブニニットは蹯水領域を中にして外側を 漞水性フミ/酸残基の殼でおおった油滴構造をとってい ると考えられている。各サプニニットはその中にらせん 構造が $5 \%, \beta$-構造が $35 \%$, 残り $40 \%$ は不規則構造か 

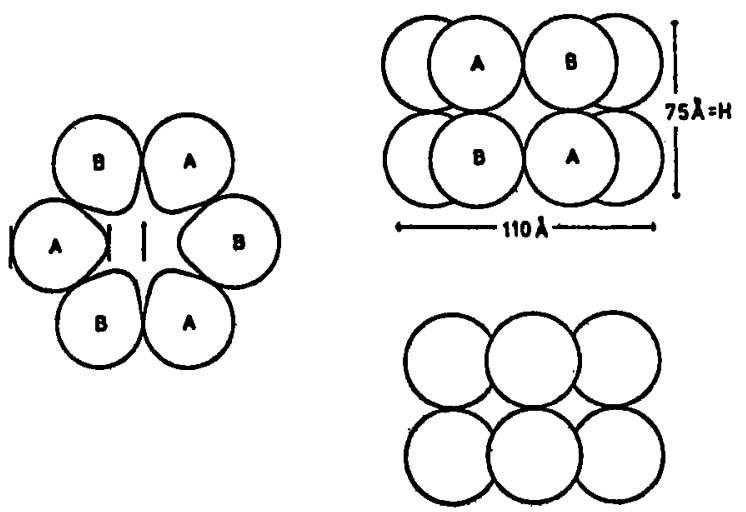

因2.11S(グリシニン)の立体構造

A：酸性サブュニット

B：盐基性サブュニット

らなっている。分子量やサプニニット組成の異る $7 \mathrm{~S}$ む この割合はほとんど変らない。7 Sと11Sはサブニニッ 卜組成は異るが，11Sは中間サブニニット 3 個が集って 環状で半量体をつくり，これが図2のように2段になっ て11Sを形成している。7 Sは3 個のサブユニットが図 1 のように3 個で環状となり，低イオン強度ではこれが 2段となってダイマーを形成している。このように 3 個 の単位か環状に 2 段になって形成されるという共通点が 存在する。

大豆タンパク質の加工過程における電子顕微鏡的観察 む，推定でなく直接的な情報を与えてくれるので有用で 亦る。とくに走查型電顕は立体的な像を与えてくれる。 脱脂大豆，浱縮タンパク質を観察すると，これらにもプ ロティンボディが含をれている。しかし製法によって球 体の崩壊の仕方が異っていた ${ }^{68)}$ 。また等電点のままの分 離タンパク質の表面は荒く，中和したものは表面が滑ら かであった。等電点沈澱およびカルシウム凝固でつくら れた末变性タンパク䝷の凝集物は球状を示すが，加熱变 性させると網状構造を形成した。さらに凍結すると綱状 構造はより明確に大きくなりその物性との関連も調べら れた54。構造解析の手段としてフシドレッドの大豆タン パク質との結合によるメタクロマジーが報告されてお り，構造変化の目安となろう ${ }^{65) 。 ~}$

\section{大豆タンパク贒の溶解性と分画 ${ }^{5,1001}$}

大豆タンパク質を利用する際にまず始めに溶解させて 利用する場合が多い。安た檂厚溶液として使用するとき にはその溶けている部分がおるに物性に関与することも ある。一般に溶解性は乳化性や起泡性と平行関係にある
といわれ，物性としても重要な性質である。溶解性の 尺度としてタンパク質照濁液を遠心分雖後，上澄液の Nを計る窒素溶解指数 (NSI) がしばしば用いられそ の目安としては有益である。しかし溶解の方法や56),

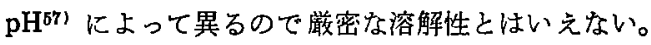

大豆タンパク質の溶解度はまず $\mathrm{pH}$ によって大きく 変化する。 $\mathrm{pH}$ が 4 5 で最少の溶解度となるが，こ れは等電点と一致する。この $\mathrm{pH}$ 加遠ざかる程酸性 でるフルカリ性でも溶解度は上昇するが，酸性側ては 解離などの変化を起しやすいので，抽出には $\mathrm{pH} 7 \sim 9$ がよく用いられる。pH８のトリス塩酸緩衝㖡で抽出 した溶液を $\mathrm{pH} 6.4$ に低下させると $11 \mathrm{~S}$ の大部分が沈 澱し， $7 \mathrm{~S}$ と $2 \mathrm{~S}$ 溶解しているので粗分画に用いら れる14!。抽出時にメルカプトエタノールを加えるとタ ンパク質の会合を防き抽出率を増加させるる ${ }^{581}$ 。市抽 出率はオートクレープ後に超音波処理を行うと著るしく 増大した ${ }^{59}$ 。大豆グロブリンの $10 ３ 0 \%$ の濃い状態で は, イオン強度が低いある範囲内で二層にわかれ，その 上層は浴解する濃度に打いて, $\mathrm{pH}$ を变えた場合の抽出 カーブとよく一致した ${ }^{80)}$ 。

酸沈澱させたタンパク質を中和しても不溶物が残る。 この量は水抽出タンパク質の 20 ～ $30 \%$ にも達する。これ 以酸性に鋭敏な画分すなわち ASF (Acid Sensitive Fraction）と呼ばれる不溶性タンパク質部分が存在する からである ${ }^{61,62) 。 \mathrm{pH}} 4.5$ にした酸沈潵タンパク質に食 塩を加えると次第に溶解してくるが， $1 M$ の濃度で溶け ない画分を ASF とし，この条件の不溶物の量から定量 する。この画分は大豆臭として嫌われている grassy beany flavor を多く含む68?。

つぎに豆腐をつくるときに使用されているように Ca や $\mathrm{Mg}$ などの金属イオンはタンパク質の溶解性を下げ确 集させる。11Sは $7 \mathrm{~S}$ よりもCaイオンに対して鋭敏で， より低濃度で凝集させうるので粗分画に利用されてい る。これらの金属イオンは一般にカルボキシルイオンな どの陰性基に結合するものと考えられるが, $11 \mathrm{~S}$ と $7 \mathrm{~S} に$ ついては，これらのタンパク質中のヒスチジンと結合す るという報告がなされた ${ }^{64-67) 。 し か し C a イ オ ン と 11 ~ S ~}$ の相互作用による体積変化をデラトメーターで測定した こころ, Ca との特異反応というよりはむしろ水や柾水結 合の变化によって起る塩析，塩容变化と考えられた ${ }^{68)}$ 。

水抽出したタンパク質溶液を $0 \sim 4^{\circ} \mathrm{C}$ に冷却すると沈澱 が生ずる。これは冷沈澱画分 (CIF, Cold Insoluble Fraction) と呼び， $11 \mathrm{~S}$ が大部分 $(69 \sim 88 \%)$ で簡単に 分画できるのでしばしば用いられてきた方法である。冷 


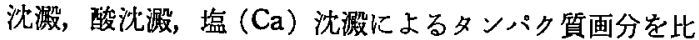
較すると，塩沈澱させたるのが収量むよく，夾雑物の混 入も少なく食品工業的利用に適していた ${ }^{69)}$ 。水抽出後酸 沈澱によって得られた大豆分離タンパク（Soy protein isolate）は，签媒処理によって低分子を除いただけの大 豆濃縮タンパク (Soy protein concentrate)よりも $\mathrm{pH}$, 温度变化させて測定した溶解性は高かった おける溶解性は， $\mathrm{pH}$, 温度と共に，その液量，共存塩類 などが影響し，さらにタンパク質がそれまでの過程でど のような変性を受けてきたかなどによる。

大豆タンパク質製品は水分を除いた脱水状態で眝蔵さ れることが多いが，一般的に乾橾前のタンバク檂度が低 いほぞ，加熱条件が温和なほど不溶化は防げる。亜硫酸 ナトリウムを加えるか，または $\mathrm{pH}$ を 9 に上げて噴霧乾 燥すると分散性は高まった ${ }^{71)}$ 。一方脱水タンパク質の保 藏中の不溶化も著るしく, 常温 $\mathbf{3}$ カ月で可溶性タンパク 質が 95\%から 30\% に低下することもあるといわれる。 この不溶化度は水分之温度によって異なり，水分 $10 \%$ 以 下, 温度 $5{ }^{\circ} \mathrm{C}$ 以下では 10 カ月以上たっても不溶化は起ら ない79)。高温 ${ }^{73)}$ また高温高湿 ${ }^{74)}$ に貯蔵した丸大豆は NSI および豆乳抽出率が減少した。このとき水抽出画分 の7Sは11Sよりも比率が增加した71)。大豆結維状タン パク質の䝪蔵中の変化においても，温度が高い程溶解性

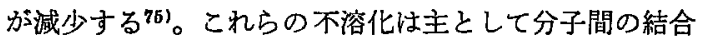
と水素結合, 疎水結合によって起るといわれる。丸大豆 をてルコール浸漬して粉碎すると NSI は低下するが, フレーバーが向上した大豆タンパク質が得られた ${ }^{76) 。}$

大豆タンパク質を化学修飾すると，フシル77 799化で等 電点はより酸性側に移り，サクシニル化やてセチル化の 程度が進む程，無処理のものと比べ等電点より酸性側の 溶解度が低くなり，等電点より $\mathrm{pH} 7 \sim 8$ までの溶解度は アシル化で增加した。

大豆の主な水溶性タンパク質をヒドロキンフパタイト による1回のカラムでの分離が報告された ${ }^{80) 。 し か し そ ~}$
れぞれのタンバク質の純度についての証明は不充分であ る。大豆に多く含まれているフィチンと11 Sの結合状態 が各種の $\mathrm{pH}$ で検討され，等電点以上では結合しておら ずゲル沪過で分䜅できた ${ }^{811}$ 。またフィチンの各種の除去 法が検討された ${ }^{82,161) 。 ~}$

\section{大豆タンパク質の食品物性"}

大豆タンハクク質は豆乳のような液体の飲料から豆腐の ようなゲル状態そてして人造肉のような固体に到るまで 多様な物性を持ち，これほど多くの変化ができるタン八 ク質はあまり例をみないであるう。これまでタンパク質 の構造と物性との関運は，直接的な解明はあまり多くな されていないが，興味あるのは7 Sと11 Sの物性の相違 で，各種の伝統的食品の機能的特性が表 4 の上うにまと められている881。このように物性が明らかになることに よって，目的の食品に適したタンパク質のみによる製造 や，また必要なタンパク質の多い品種の選択などに応用 されるであるう。

最近農林水産省は植物性タンパク質の日本農林規格を 制定し，タンパク質製品の品質の基準を示した84)。その 項目は水分, タンパク質含量, ゲル形成能, 乳化性, そ しゃく性, 保水性, 粘稠度でありその測定法が述べられ ている。これらの項目はタンパク質の物性を代表してお り，その方法と共に参考になる。

(1) 乳化特性 (脂質との結合) ${ }^{101}$

脬化特性の測定方法を大別すると，まずタンパク質溶

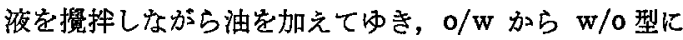
転相するまでの油の量を計る乳化力 ${ }^{851}$ ，释化容量奋) (Emulsifying capacity) $^{87}$ 測定法がある。つぎにタン

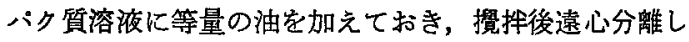
て中間にできるエマルジョンの層の高さ又は容積を計る 乳化能息), 䄻化活性 ${ }^{88)}$, 乳化力 ${ }^{89)}$ (Emulsifying activity $)^{90}$ 測定法がある。またタンパク質溶液と油を䚋拌 して一定時間後に下層の一定量をとりだし，水分含量を

表 4. 7S，11Sの食品飞打ける機能的特性

\begin{tabular}{|c|c|c|c|c|c|}
\hline 成 分 & 豆 & 沵 至席 & 油揘 げ & チース㮶食品 & 㑥 \\
\hline $7 \mathrm{~s}$ & 柔らかく付着性がある & 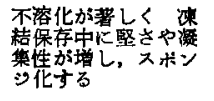 & $\begin{array}{l}\text { 伸展性が小さく，柔 } \\
\text { らが }\end{array}$ & 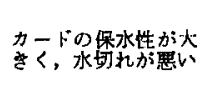 & 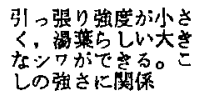 \\
\hline $11 \mathrm{~S}$ & 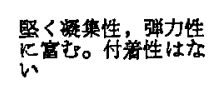 & 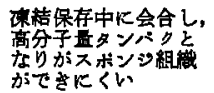 & 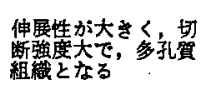 & $\begin{array}{l}\text { カードの水河扎が } \\
\text { く色䊩も明るい }\end{array}$ & $\begin{array}{l}\text { 引っ唇り強度大きく， } \\
\text { シワが少ない }\end{array}$ \\
\hline
\end{tabular}


計る乳化安定性 ${ }^{85)}$ (Emulsion stability) 測定法がある。 これは下層の水分含量が多くなるほど不安定であること を示す。ほ加浮化安定性は乳化力定測定後。エマルジ ョンが崩壊する時間を計ったり，乳化力を計る際にエマ ルジョンを加熱して後に遠心分離してェマルジョン層を

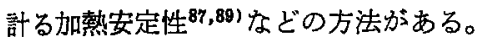

以上の用語は同じでも測定方法が異る場合もあり，同 じ方法でむ用語が異っているのでいうれは統一されるバ きであらう。乳化容量と乳化安定性はある程度試料が必 要であるが，乳化活性はより少くて済む。最近他のタン バク質で用いられた吸光度による濁度法"11はより少量で 㨈むであろう。しかしどの測定法が最も食品加工に相応 しているが問題があり，以上の測定法は必ずしも実際 の利用と一致しない場合むある。これは乳化する食品の 性質が種類によって異るためで，肉の多いンーセージな ぞのミート型, 粘度が低い液状のミルク型, 粘度か高く 脂肪の多いマヨネーズ型の 3 種のエマルジョンにわけ， 製品に近いモデル中の挙動でタンパク質の乳化特性を評

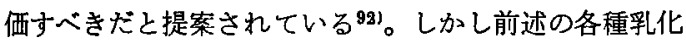
特性測定法は，乳化に関するタンペク質の傾向を知るス クリーニングには有効であろう。

乳化特性とタンパク質との関係は，一般にタンパク質 浱度が增すと見かけの值は增すが，単位タンパク重量当 りに換算すると減少している。乳化容量は $\mathrm{pH}$ が等電点 に近い程減少し，遠くなるほど堌加している85,88)。イオ ン強度の影響は $0 \sim 0.05$ まで上昇するが，それ以上は変 化しない85!。乳化安定性は乳化する装置によって異な り，㨨拌力が弱いと時間依存性が大きく，超音波処理を

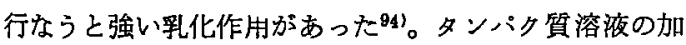
熱㠜集物が多い程，乳化活性が大きく，また溉粉ゲル電 気泳動によってエマルション層のタンパク質組成が検討 されている88)。大豆タンパク質製品ではその成分中タン パク質合量が多い程乳化特性が大きく ${ }^{90)}$ ，分離タンパク 質は源維タンパク質より乳化安定性が大きい(95)。醉素や 酸による加水分解によるとある条件で䟭化特性加上昇す

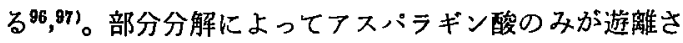
れ，他のアミノ酸方まだ遊離されない段階が最も拜化特 性が大きい，部分分解タンパク質は等電点頒域にお打る 乳化特性の低下が全く消え $\mathrm{pH}$ 全域にわたって高い值を

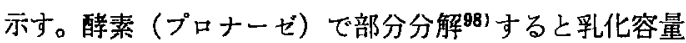
は増加したが，乳化安定性は減少した例あある。高タン パク質溇度 ${ }^{999}(17.5 \%)$ では熱変性タンパク質に比べて 末変性タンパク質の方が著るしく高い乳化力を示し，乳 化安定性は蔍䌅の添加で涷結に対する安定性がかなり向
上した。

サクシニル化による化学修飾では, 釈化活性, 乳化安 定性が幾分増加し ${ }^{77)}$ ，乳化容量は著るしく增加した ${ }^{77,799}$ 。 サクシニル化物の～ $\mathrm{pH}$ による变化では溶解性の大きいむ の程大きかった。これに比べててセチル化ではあまり変 化がなかったこれらは $90 \%$ 以上のアシル化の場合で あるか，フセチル化の度合を変え漸次多くした場合， $\mathrm{pH} 4.5$ 附近ではフセチル化の度合が增す程乳化力は增 加した ${ }^{77}$ 。サクシニル化の場合は中性附近では大きな乳 化力を示すが $\mathrm{pH}$ が下る程低下する77,79!。

$7 \mathrm{~S}$ と11Sのアセチル化物を比較すると，乳化活性汢 両者ともフセチル化が進む程低下するが，乳化容量と乳 化安定性は，7 Sではアセチル化が增す程增加するが， $11 \mathrm{~S} て ゙ は 60 \%$ マチル化まで増加し，90\%になると逆に 减少した ${ }^{86)}$ 。このように11Sが特異的に变化するのは， フミ/基の修飾によって11Sが一部解䜅すると共に大部 分は重合が起り，油との結合部位が隇少したことが知ら れた ${ }^{102 ! 。}$

大豆タンパク質とリン脂質の結合性が電子スビン共 鳴 1081 中密度勾配遠心法 ${ }^{104)}$ によって調べられ，超音波処 理によると $7 \mathrm{~S}$ 及び $11 \mathrm{~S}$ より多く非特異的に結合し， さらに油との複合体が形成された。また変性郕でタンパ ク質を解離させるとリン脂質との結合が増し，さらに油 とよく結合する。油との結合は，まずタンパク質の変性 によるサブニニットへの解離によってその表面積が大き くなり疎水基がより露出することが必要で，この原理は

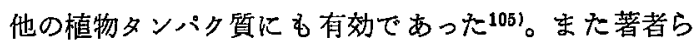
は量的には少いが柾水性てミノ酸の多い特殊なタンパク 質と脂質が結合したブロテオリピドを脱脂大豆及び大豆 食品中から分離して㧍り 106 108)，このタンパク筫のサブ ユニットは7 7 や $11 \mathrm{~S}$ サブュニットと異なるむので, 乳化特性などへの効果を検討している。リノール酸過酸 化物と大豆 $11 \mathrm{~S}$ との反応系 ${ }^{109}$ に打いては, 酸性サブニ ニットが塩基性サブニニットより容易に重合物を生成し た。

\section{（2）泡特性}

泡特性は起泡力 (Foam expantion ${ }^{110)}$ ) と泡安定性 (Foam stability ${ }^{110)}$ )にわけられる。起泡力はタンパク

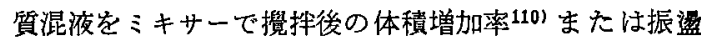
後の体積901で計る方法がある。泡安定性は一定量の泡を 満したビーカーを逆にしメスシリンダーへの滴下量から 求めるの ${ }^{110)}$ と，振盪後一定時間索経て体積の減少量を計 ったり ${ }^{90)}$ ，一定量の泡から汇過で滴下寸る水量や 1 滴の 時間112などを測定する。 
起泡性は溶解性や乳化特性に似て，等電点附近で減少 する110,112)。しかし泡安定性はこの逆で等電点附近で最 高である。低変性の脱脂大豆程起泡性が高い110)。プロナ 一ゼ処理による加水分解では起泡性は増すが泡安定性は 低下した ${ }^{98)}$ 。サクシニル化による化学修飾では泡特性が

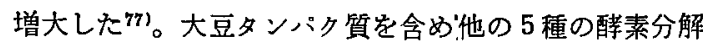
物の泡安定性と分子構造との関係を調べると，釈化特性 と同㰀にタンパク質表面の性質が重要であることが知ら

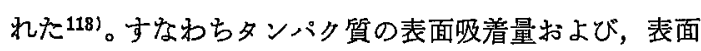
近くの疎水域方゙多い程泡安定性は増加し，中の部分の疎 水域含量とは関係なかった。この際醉素分解によって表 面に露出した疎水領域は再び内部に埋めこまれやすい 茫，S-S 結合が多い程この再配列を防ぎ表面疎水領域を 維持する。

（3）水分特性

水分特性は保水性 ${ }^{114}$ ) (Water-holding capacity ${ }^{115)}$, Water retention capacity ${ }^{76}$ ) 。水分結合性 (Water binding(18), Water absorption ${ }^{117)}$ ), 水分活性 (Water activity $^{118)}$ ), 結合水 (Bound water ${ }^{19)}$ ) にわけられる。 保水性はタンパク質分散系を加圧して, 残存する水分重

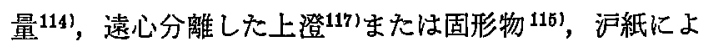
る沪過水量76)などで測定する。水分結合性は一定蒸気生 を保つ塩飽和水溶液 ${ }^{(16)}$ または各濃度の硫酸混液 ${ }^{(18)}$ 上で タンパク質が含む水分量定測定する。水分活性は試料の 示寸蒸気圧と,その温度での水の飽和蒸気圧との比で, 各 種既知蒸気压を示す溶液上での水分含量の増減をしらべ る法, マノメーターによる方法 ${ }^{120)}$ な゙がある。結合水は

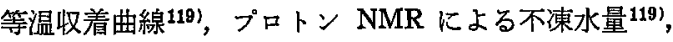

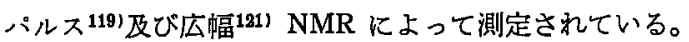

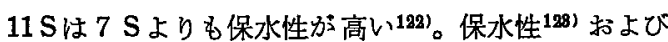
水分結合性 ${ }^{186}$ は溶解性と似て, $\mathrm{pH}$ が等電点から通ざか る程上昇する。保水性の塩による影響が調べられてい

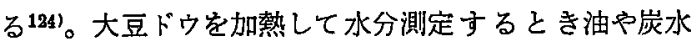
化物が混在していても $105^{\circ} \mathrm{C} ， 24$ 時間加熱で水分含量は 比較的正確に測定されるが，高タンパク質濃度になると 強大な水との結合力と乾燥固化によって不充分な水分合 量となる ${ }^{126)}$ 。保水性を高めるよう種々の变性を試みた ところ，0.5Mの尿素で变性させ $150^{\circ} \mathrm{C}$ で加熱させると 最も保水性の高い大豆タンパク質が得られた ${ }^{115}$ 。大豆線 維状タンパク質を各種温度で 2 カ月間販藏したところ高 温に置いたもの程保水性が低下した ${ }^{75)}$ 。分離タンパクを 加熱すると水分活性肪 0.8 以下のときは未加熱試料より 低い水分含量を示すが，0.8 以上のときは未加熱試料の 方が高かった ${ }^{(26) 。 ~}$
大豆濃維タンパク中の水を NMR と等温収着式によっ て測定したところ，6.4\%の堅い結合水と $26 \%$ 迄のゆる い結合水と，それ以上の遊離水の 3 種の状態の水に区別 された ${ }^{119)}$ 。濃縮タンパと分離タンパクの種々の水分 含量における結合水を比較すると，分離タンパクは水分 含量の增加につれて結合水は次第に増加して $49 \%$ に近う く。しかし濃縮タンパクは水分含量にかかわらず結合水 は24\%で一定だった。超音波処理すると結合水が増加し はじめる。よって分離タンパクは細胞構造をしており， タンパク質の膨潤を妨たげているが，超音波によって細 胞構造が破壊されたものと考えられる。分離タンパクは 細胞構造をむたず結合水含量 49\%は KNITZのアミ/酸組 成からの計算と一致している。をた等温収着曲線は充分 に時間を置くと，吸水と脱水の差がみられなかった。両 者の間に差がみられるヒステレスを示すむのは平衡時間 肪短い為と考えられる ${ }^{127) 。 ~}$

大豆濃縮タンパクの吸水及び脱水過程を動力学的に調 べると ${ }^{128)}$ ，はじめの急なステップと，つぎのゆっくりし たステップがある。はじめのステップは細胞閒の吸水, 脱水で，つぎの過程は細胞壁を通した水の移動に基う く。水抽出した分離タンパクは直線で第 2 のっくりし た過程がなかった。

広幅 $N^{2}{ }^{121)}$ による大豆粉末では，全水分の NMR シグナルに対する水分含量を図に畫くと結合水含量 (Bound water capacity) のところで折れた直線となっ た。結合水のみのシグナルと水分含量の図では，絬合水 含量のところで頂点となる三角形を示し，頂点の水分含 量は全脂粉では $28 \%$ ，脱脂粉では $40 \%$ であった。

(4) 凝固性とテクスチャー6,129)

大豆タンパク質溶液または加熱して出来るゲルの粘弾 性測定に使用されている機器は 3 種に大別される180)。 第 1 は基礎的力学量の測定で，回転粘度計として B型粘 度計 ${ }^{181) ， レ オ メ ー タ ー ~}{ }^{182,1881}$ により粘度，チクントロピ 一, 動的粘性率, 動的弾性率, 緩和スペクトルが, また 平行板プラストメーター184)により静的弾性率と静的粘 性率,クリープ曲線が測定された。第 2 ははっきりした 力学的特性值でないが, 力学量と関係つけられる測定機 がペネトレーター186), カードメーター1881, ジェリー強度 機187で，これらによってゲル強度，破断力などが測定 されている。第 3 は模擬的測定機とも呼ばれるもので， そしゃくしたり手でこねたりするときの力学的条件を模 倣して測定されるもので, テクスチュロメーター187)，レ オロメーター184kよって硬さ, 凝集性, 粘性, 弾力性, 附着性などのパラメーターが一度の測定で簡便に出来 
る。フミログラフ 188)もこの種類に属する測定機である。 よく使用されるカードメーター, ジェリー強度機, テク スチュロメーターの各ハララメーターの相関性を比較する と，硬さ，弾力性，附着性の三成分に大きく分類でき 万(187)。

一般にタンパク質の濃度が 7 8\% 以上で，温度が $70^{\circ} \mathrm{C}$ 附近以上になると㠜固してゲル化が洼じまる。 $\mathrm{pH}$ による加熱ゲルの強さは中性よりも酸性 ( $\mathrm{pH} 2 \sim 3)$ や丁 ルカリ性（pH 11〜12）処理したものが硬いゲルが出来

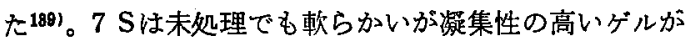
出来た。同様に $\mathrm{pH} 12$ で変性させたタンパク質がもっと も粘性家增した。これは unfolding した分子がさらに S-S結合により重合したと推定され，さらに $\mathrm{pH}$ を 13 以 上にするとシスチン残基も破壊され粘性む低下した ${ }^{1491}$ 。 加熱ゲルの形成はイオン強度によっても影響され， $7 \mathrm{~S}$ は高イオン強度の加熱で㠜集物が出来やすく，11 S に低イオン強度で変化しやすく，サブニニットに解離し 部分的に凝集する186)。各種醉素で処理した加熱ゲルを 比較すると，植物ブロテアーゼで処理したものが動物起 源の酵素より良好なゲル特性を示した141)。

豆乳を加熱したとき高い濃度で加熱したもの程硬いゲ ルが出来, 0.2 以下のイオン強度ではイオン強度の高い

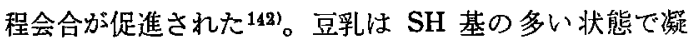
固させたるのほど堅い豆腐ができるので，豆乳を長く加 熱すると空気による酸化が起るので $100^{\circ} \mathrm{C}$ 加熱後直ちに に冷却して凝固するとよい148)。Ca 瘟で㠜固させた豆糜 は比較的柔かいが壇れ難く、グルコノデルタラクトンで 凝固させた豆腐は比較的堅いが壊れやすい。両者の化学 的な此較を行なうと Ca 橋が重要な相遠をむたらしてい た ${ }^{144)}$ 。大豆タンパク質㲘濁液（1７\%）は Ca 添加によ り粘度は上昇し，添加前の $80^{\circ} \mathrm{C}$ の加熱が大きな勃果が ある145!。

脱脂大豆を高温で加熱して押出すなどの各種の加工法 によって出来るタンパク質の溶解性を電気泳動法で調べ た ${ }^{148)}$ 。100 $170^{\circ} \mathrm{C}$ まで高温加熱すると $105^{\circ} \mathrm{C}$ を最低に して高温になる程溶解性が增し，ゲル電気泳動では次第 に分解してピークが減少するが，一般に 7 Sは11Sより もこの変化が達い147。 。ンパク質を高温で加熱すると 分解してアマイドが减少し，フンモニアが生成し，色素 との結合量が減る148)。

大豆タンパク質のゲルのレオロジー的性質が測定され ると共に，卵白ゲル，寒天ゲルとのテクスチャ一の比較 がなされ，大豆タンパク質ゲルは凝集性が大であり附着

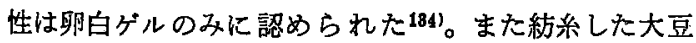

タンパク質の動的粘弾性が測定され，カゼインより劣る がパン醰母タンハク質と同じ位の紡絓性を示した ${ }^{1881 。}$ 亜硫酸ンーダ ( $1 \%)$ を加えて水抽出後, $\mathrm{pH} 5.5$ の上澄 を $\mathrm{pH} 4.5$ で沈激させた画分は，通常の大豆タンパク質 とは異った機能特性を示し，50\%に達する高い漲度で も，等電点及び中性の $\mathrm{pH}$ で流動性を示した ${ }^{149 \% 。(ほ か に ~}$ 湯葉のように豆乳の加熱によって出来る可食性フィルム の調製1501 と肉への混用が報告されている151)。

大豆タンパク質は凍豆腐のように凍結によって凝固し 著るしい物性の变化を示す。凍結期間中に括汀る粒子は 電子顕微鏡户各種变性抄による溶解性の变化加ら凍結中 の結合様式が推定された ${ }^{152)}$ 。凍結変性に効果的な各種 条件を考虑して収量よく海綿状の新タンパク食品素材が 製造され,ソーセージやシウマイに添加してかなり良好 な成績を収めている153)。

大豆タンパク質は肉製品への混用が行なわれているの で，その基礎的研究としてミオシと $7 \mathrm{~S}^{164)}$ ，及びミオ シンBと11 S (CIF) ${ }^{156-158) ~}$ が検討された。

\section{ま と め}

大豆タンバク質の化学構造に関しては最近著るしく進 步し，主成分の $11 \mathrm{~S}$ 己 $7 \mathrm{~S}$ のブユニット構造が決定さ れた。これによって物性の構造解明に大きな手掛りを得 た。サブユニット間の結合については11 Sの S-S 結合は 明らかになったが861，他の非共有結合の種類などが今後 の問題とならう。食品加工に括ける大部分の変化は分子 内及び分子間結合の相互作用が多いので，サブュニット 間の結合はその基礎となる重要な性質である。なお疎水 結合，水素結合，イオン結合なぞの非共有結合は，多く の場合推定が多くタンパク質の立体構造が複雑なととも 関与して直接的な証朋が出来にくいが，今後食品化学と してもとの結合の種類及び割合の測定の開発を重要な課 題とすべきであろう。

タンパク質の物性は分子が解離しているか会合してい るかその分子量の大きさで左右される。同じ大きさでる 形分球状棒状か, compact か, unfold かによっても 異るであろう。以上の外最近分子の表面や，表面中の科水 基の量と分布などが物性を支配することが知られてきた ので，これらをより正確に測定する方法も検討されるべ きであろう。

つぎに今迄の文献から知られる一般的な構造と物性と の関連をのべると，まず大豆タンパク質の溶解性は概し て未变性の状態の方が良好である。 $\mathrm{pH}$ を微アルカリ性 
にするとより溶解度は增す。しかし $\mathrm{pH}$ を 10 以上にする と高次構造が破壊され，他の変性と同じく疎水基なども 露出してくるので望宝しくない。

つぎに釈化特性, 泡特性, 水分特性, ゲル形成などの 機能特性を増大させるのに共通した点は，はじめに解離 または部分分解させることである。解離にはフルカリ 性，尿素などが有効で，加熱は時に有効であるが，重 合，沈淑化む同時に起るので不適当な場合もある。部分 分解には䤃素又は酸が用いられる。大豆タンパク質は変 性戍家除去すると，それ自身の性質によって復元し多く は再び会合する48,164)。

乳化特性はタンパク質を解離または部分分解させるこ とによって表面積を大きくし，かつ除水基を露出させる ととによって油との結合力が増大する105)。泡特性む同 様の原理で表面吸着性 113 妾増大させ油の代りに空気が 入ることになるう。水分特性の中でとくに保水性は，变 性によって解離させ，解離後に会合を促進させる処 理115)を行う。会合させるには濃緶，乾燥，凍結などに よって分子をより接近させ相互作用を促す。ゲル形成も タンパク質分子により多く水を含む反応なので，原則的 には保水性と同し原理で増大させうる。水分特性の場合 も表面の大きさが大切とみられあるタンパク質では結合 水を重量\%ではなく，タンパ少筫の表面積当りに対して 計算した方がより溶解性と一致するという例がある1599。

以上のように解離と会合の二段階によって機能特性は 改良しうるであるうが，解離に用いる変性の方法で食品 こして利用できない变性刘るあるので食品工業では工夫 が必要である。

以上大豆タンパク質の構造と物性について主に最近の 目にふれたレポートについてのべたが，物性発現の構造 的解明はまだ多くのことが未知である。しかしタンパク 質の構造研究は近年著るしく進歩しており，その構造解 析の手法を用いれば物性との直接的な関連の追求はより 容易になってきた。また最近食品関係の分野の物性に関

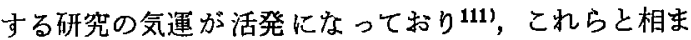
って今後より多くの事が解明されるようになるである う。

\section{文献}

1）渡辺篤二ほか：食の科学, No. 29 , 臨時特集ダイ ズ蛋白食品 (1976).

2) Smith, A.K. and Circle, S.J.: Soybeans: Chemistry and Technology, vol. 1, Proteins, The Avi Publishing Co., In., Westport, Con- necticut. (1972).

訳書, 渡辺篤二・柴崎一雄監修：大豆タンパク 質，（建帛社）(1974）。

3）越山有則：植物醇素・蛋白質研究法，(共立出版), p. 456 (1976).

4）齐尾恭子：食品工誌，20，374（1973）.

5）青木 宏：日本食品工業学会第 22 回大会シンボ ジウム, p. 54 (1975).

6) Wolf, W.J.: Advances in Cereal Science and Technology, 1, 325 (1976).

7) 福島男児：醬研，3，22（1977）。

8) Wolf, W.J.: J. Am. Oil Chem. Soc., 54, 112A (1977).

9）交献 2) 訳書, p. 217.

10) Koshiyama, I. and Fukushima, D.: Phytochem., 15, 161 (1976).

11) Koshiyama, I. and Fukushima, D.: Phytochem., 15, 157 (1976).

12) Irbuchi, C. and Imahori, K.: Agric. Biol. Chem., 42, 25 (1978).

13) Hill, J.E. and BReidenbach, R.W. Plant Physiol., 63, 742 (1974).

14) Thanh, Vu Huu and Shibasaki, K.: J. Agric. Food Chem., 24, 1117 (1976).

15) Thanh, Vu HuU, OKubo, K. and Shibasaki, K.: Agric. Biol. Chem., 39, 1501 (1975).

16) Thane, Vu Huu, Okubo, K. and Shibasaki, K.: Tohoku J. Agric. Res., 25, 41 (1975).

17) Thanh, Vu Huu Okubo, K. and Shlbasaki, K.: Plant Physiol., 56, 19 (1975).

18) Thanh, Vu HuU and Shibasaki, K.: Biochim. Biophys. Acta, 439, 326 (1976).

19) Thanh, Vu Huu and Shibasaki, K.: Biochim. Biophys. Acta, 490, 370 (1977).

20) Thank, Vu Huu and Shibasaki, K.: J. Agric. Food Chem., 26, 695 (1978).

21) Hill, J.E. and Breidenbach, R.W.: Plant Physiol., 53, 747 (1976).

22）浅野三夫・柴畸一雄：食品工誌，20，126(1973).

23）浅里三夫・宮本義厇・大久保一良・柴崎一雄：食 品工誌, 21 261 (1964).

24）浅野三夫・宇野和生・柴崎一雄・大久保一良：食 品工誌, 24, 607 (1977).

25）浅野三夫・宇野和生・柴崎一雄・大久保一良：食 品工誌, 25, 88 (1978).

26) Yanagi, S,, Fukazawa, C. and Harada, K. Agric. Biol. Chem., 42, 697 (1978).

27) Lowry, K.L., Caton, J.E. and FoARd, D.E.: J. Agric. Food Chem., 22, 1043 (1974).

28) Draper, M. and Castimpoolas, N.: Cereal Chem., 55, 16 (1978).

29) Koshiyama, 1.: Agric. Biol. Chem., 30, 646 (1966).

30) Kosmiyama, I. and Fukushima, D.: Cereal 
Chem., 53, 768 (1976).

31) Yamauchi, F., Kawase, M., Kanbe, M. and Shibasaki, K.: Agric. Biol. Chem., 39, 873 (1975).

32) Yamauchi, F., Thanh, Vu Huu, Kawase, M. and Shibasaki, K.: Agric. Biol. Chem., 40, 691 (1976).

33) Draper, M. and Catsimpoolas, N.: Phytochem. 16, 25 (1977).

34) Kitamura, K. and Shibasari, K.: Agric. Biol. Chem., 39, 945 (1975).

35) Kitamura, K. and Shibasaki, K.: Agric. Biol. Chem., 39, 1509 (1975).

36) Kitamura, K., Takagi, T. and Shibasaki, K.: Agric. Biol. Chem., 40, 1837 (1976).

37) Kitamura, K. and Shibasaki, K.: Agric. Biol. Chem., 41, 351 (1977).

38) Lynch, C.J., Rha, C.K. and Castinpoolas, N.: Cereal Chem., 54, 1282 (1977).

39) Lynch, C.J. Rha, C.K. and Castinpoolas, N.: J. Sci. Food Agric., 28, 971 (1977).

40) Kamata, Y. and Shibasaki, K.: Agric. Biol. Chem., 42, 2103 (1978).

41) Kamata, Y. and Shibasaki, K.: Agric. Biol. Chem., 42, 2323 (1978).

42) I IBUChI, C. and Imahort, K.: Agric. Biol. Chem., 42, 31 (1978).

43) Thanh, Vu Huu and Shibasaki, K.: J. Agric. Food Chem., 26, 695 (1978).

44) Yamauchi, F., Sato, W., Kamata, Y., and Shibasaki, K.: Fifth International Congress of Food Science and Tech. p. 179 (1978).

45) LeE, Y.B., RickansRud, D.A., Hagberg, E.C., BRISKRY, E.J. and Greaser, M.L.: J. Food Sci., 40, 380 (1975).

46) 橋詰和宗・野口明德：食品工誌， $25 ， 628$ (1978).

47) 橋詰和宗・小原忠彦・安藤洋子：食品工誌, 25 , 635 (1978).

48) Kotula, A.W. and Rough, D.K.: J. Food Sci., 42, 731 (1977).

49）飯島淑子：食品工誌，24，516 (1977).

50) BaILEY, F.J.: J. Sci. Food Agric., 27, 827 (1976).

51) Badley, R. A., Atkinson, D., Hauser, H., Oldani, D. Green, J.P. and Stubbs, J. M.: Biochem. Biophys. Acta, 412, 214 (1975).

52) Koshiyama, K. and Fukushima, D.: Int. J. Peptide Protein Res., 8, 283 (1976).

53) WoLf, W.J. and BAKER, F,L.: Cereal Chem., 52, 387 (1975).

54) LeE, C.H. and RhA, C.: J. Food Sci., 43, 79 (1978).

55）内田常雄 - 石井謙二：曹化，51, 573 (1977).

56) Shen, J.L.: Cereal Chem., 53, 902 (1976).
57) Shen, J.L.: J. Agric. Food Chem., 24, 784 (1976).

58) NASH, A.M., KWOLEK, W.F. and Wolf, W.J.: Cereal Chem., 51, 220 (1974).

59) Wang, L.C.: J. Food Sci., 40, 549(1975).

60) Van Mrgen, W.H.: J. Agric. Food Chem., 22, 126 (1974).

61) Anderson, R.L., Wolf, W.J. and Glover, D.: J. Agric. Food Chem., 21, 251 (1973).

62) Anderson, R.L.: Cereal Chem., 51, 707 (1974).

63) Anderson, R.L. and Warner, K.: J. Food Sci., 41, 293 (1976).

64) RAo, A.G.A. and Rao, M.S.N.: Cereal Chem., 52, 21 (1975).

65) RAo, A.G.A. and Rao, M.S.N.: J. Agric. Food Chem., 23, 657 (1975).

66) RAo, A.G.A. and RAO, M.S.N.: J. Agric. Food Chem., 24, 487 (1976).

67) Rao, A.G.A. and Rao, M.S.N.: J. Agric. Food Chem., 24, 490 (1976).

68) Sakakibara, M. and Noguchi, H.: Agric. Biol. Chem., 41, 1575 (1977).

69) Bau, H.M-, Poullain, B., Beaufrand, M.J. and Debry, G.: J. Food Sci., 43, 106 (1978).

70) Hutton, C.W. and Camrbel, A.M.: J. Food. Sci., 42, 454 (1977).

71) Amininlari, M., Ferrier, M., L.K. and Nelson, A.I.: J. Food Sci., 42, 985 (1977).

72) 岡本 溪・松浦加上子：食品工誌，21，23, (1974).

73）吉野梅夫 - 岩崎八重子 - 大久保 美代子 - 奥山智 子：食品工誌，54, 526 (1977).

74）齐尾恭子・有坂将美：食品工誌，25，451(1978).

75) Chiang, J.P.C. and Sterngerg, M.: Cereal Chem., 51, 465 (1974).

76) ELDRIDGE, A.C., WarNer, K. and Wolf, W.J.: Cereal Chem., 54, 1229 (1977).

77) Franzen, K.L. and Kinselda, J.E.: J. Agric. Food Chem., 24788 (1976).

78) Barman, B.G., Hansen, J.R. and Mossey, A. R.: J. Agric. Food Chem., 25, 638 (1977).

79）青木 宏・折茂則子・島津令子・若林繁子：食品 工誌, 25, 668 (1978).

80) Fisher, C.E., LEACH, I.B. and WILding, P.: $J$. Sci, Food. Agric., 27, 1039 (1976).

81) OKubo, K., Myer, D.V. and IAcobucci, G.A.: Cereal Chem., 53, 513 (1976).

82) Oкubo, K., Waldrop. A.B., I Acobucci, G.A. and Myers, D.V.: Cereal Chem., 52, 263 (1975).

83）岡本 奖: 化学と生物, 11, 433 (1973).

84）農林省: 大豆開発，37号，p. 6 (1976).

85）青木 宏, 長野宏子：食品工誌，22，320(1975).

86）山内文男 - 菱沼紀子 - 小野秀光 - 柴猗一雄：食品 工誌, 25, 446 (1978). 
87) Inklaar, P.A. and Fortuin, J.: Food Technol., 23, 103 (1969).

88）柴崎一雄・大久保一良・佐藤隆夫：食品工誌, 19 , 580 (1972).

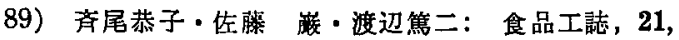
234 (1974).

90) Yasumatsu, K., Sawada, K., Moritaka, S., MisaKI, M., Toda, J., Wada, T. and Ishil, K.: Agric. Biol. Chem., 36, 719 (1972).

91) Pearce, K.N. and Kinsella, J.E.: J. Agric. Food Chem., 26, 716 (1978).

92) Puski, G.: Cereal Chem., 53, 650 (1976).

93) CRenwelge, D.D., Dill, C.W., Tybor, P.T. and Landmann, W.A.: J. Food Sci., 39, 175 (1974).

94) Tornberg, E. and Hermansson, A.M.: $J$. Food Sci., 42, 468 (1977).

95) Hutton, C.W. and Camobell A.M.: J. Food Sci., 42, 457 (1977).

96）青木 宏・松浦英子：食品工誌，23，26(1976).

97）青木 宏・岡村英子・稲見美紀：食品工誌，24， 511 (1977).

98) Puski, G.: Cereal Cham., 52, 655 (1975).

99）青木 厷・長友るみ子・堀田桂子・山口向子：食 品工誌, 24, 618 (1977)

100）文献 2) 訳書 p. 48, 190.

101）文献 2) 訳書 p. 271.

102) Yamauchi, F., Ono, H., Kamata, Y. and ShlBASAKI, K.: Agric. Biol. Chem., in press.

103) Ohtsuru, M., Kito, M., TAKeuchi, Y. and Ohnishi, S.: Agric. Biol. Chem., 40, 2261 (1976).

104) Kanamoto, R., Ohtsuru, M. and Kito, M.: Agric. Biol. Chem., 41, 2021 (1977).

105) Kamat, V.B., Graham, G.E. and Davis, M.A. F.: Cereal Chem., 55, 295 (1978).

106）山内文男・本木正雄・柴崎一雄：食品工誌，22, 281 (1975).

107）本木正雄 - 山内交男 - 柴崎一雄：食品工誌, 22, 281 (1975)

108）佐々木正治・本木正雄・山内文男・柴崎一雄：食 品工誌, 22, 309 (1975).

109) Shimada, K. and Matushita, S.: Agric. Biol. Chem., 42, 781 (1978).

110) EldRIdGe, A.C., Hall, P.K. and Wolf, W.J.: Food Technol., 17, 1952 (1963).

111）松本幸焳・山野善正編：食品の物性，第 1 集 (1975)，第 2 集 (1976)，第 3 集（1977），第 4 集 (1978). (食品資材研究会).

112) Eldridge, A.C., Wolf, W.J., Nash, A.M. and Smith, A.K.: Agric. Food Chem., 11, 323 (1963).

113) Horiuchi, T, Fukushima, D., Sugmoto, H. and Hattori, T.: Food Chem., p. 35 (1978).

114）青木 宏：農化，39，262（1965）。
115) Yanagi, S., Miyaguchi, H., Salo, K. and Watanabe, T.: Cereal Chem., 55, 157 (1978).

116) Hajenmaier, R,: J. Food Sci, 37, 965 (1972).

117) Fleming, S.E., Sousulski, F.W., Kilara, A. and Humbert, E.S.: J. Food Science, 39, 188 (1974).

118) FETT, H.M.: J. Food Sci., 38, 1097 (1973).

119) Hansen, J.R.: J. Agric. Food Chem., 24, 1136 (1976).

120）好井久雄：New Food Industry，20，(11） 1 (1978).

121) Okamura, T. Steinberg, M.P., Tojo, M. and Nelson, A.I.: J. Food Sci., 43, 553 (1978).

122）斉尾恭子・佐藤 数・渡辺篤二：食品工誌, 21, 234 (1974).

123）青木 宏：農化，39，270 (1965).

124）青木 宏：農化，39，277 (1965).

125）岡村太成・鈴木 恐・石橋憲一・東条 衛：食品 工誌, 25, 94 (1978).

126) Hermansson, A.M.: J. Food Technol., 12, 177 (1977).

127) Hansen, J.R.: J. Agric. Food Chem., 26, 301 (1978).

128) Hansen, J.R.: J. Agric. Food Chem., 26, 297 (1978).

129）古川忠康：New Food Industry, 20 (4) 45 (1978)

130) 中浜信子：調理科学, 8, 112 (1975).

131) Castinfoolas, N. and Mayer, E.W.: Cereal Chem., 47, 559 (1970).

132) 青术 宏・桜井正子：農化，43，448(1969).

133）早川功 - 川崎聖司 - 野村男次：㖘化， 49,641 (1975).

134）桑畑美沙子.中浜信子：農化，49，129（1975).

135) 青木 宏：農化, 39, 270 (1965).

136) Hashizume, K., Nakamura, N. and Watanabe, T.: Agric. Biol. Chem., 39, 1339 (1975).

137) Yasumatsu, K., Toda, J., Wada, T., Misaki., M. and IsHII, K.: Agric. Biol. Chem., 36, 537 (1972).

138) Circle, S.J., Meyer, E.W. and Whitney, R.W.: Cereal Chem., 41, 157 (1964).

139）橋詰和宗・渡辺篤二：農化，49，331 (1975).

140) Ishino, K. and Oкамото, S.: Cereal Chem., 52, 9 (1975).

141) Pour-el, P. and Swenson, T.S.: Cereal Chem., 53, 438 (1976).

142）橋詰和宗・白鳥 誠・中村則子・湾辺篤二：食品 工誌, 22, 37 (1975).

143）檑詰和宗・前田正道・渡辺篤二：食品工誌，25， 387 (1978).

144）橋詰和宗・何銀 蘭：食品工誌, 25, 383(1978).

145) LEE, C.H. and RHA, C.: J. Texture Studies, 7, 441 (1977). 
146) Cumming, D.B., Stanley, D.W. and Deman, J.M.: J. Food Sci., 38, 320 (1973).

147) Saio, K., Teyashima, M. and Watanabe, T.: J. Food Sci., 40, 537 (1975).

148) Sa10, K., Terashima, M. and Watanabe, T.: J. Food Sci., 40, 541 (1975).

149) Shemer, M., Creinin, H.L., Mcdonald, R.E. and IRWIn, W.E.: Cereal Chem., 55, 383(1978).

150) Wu, L.C. and Bates H.P.: J. Food Sci., 783 (1973).

151) Wu, L.C. and Bates, R.P.: J. Food Sci., 40, 160 (1975).

152）川口 豊: 栄養之食糧, 28, 337 (1975).

153) 橋詰和宗：食糧一その科学と技術一 17 号, p. 55 (1975).

154) KIng, N.L.: J. Agric. Food Chem., 25, 166 (1977).
155）芳賀聖一・大橋登美男：食品工誌, 24, 243(1977).

156）芳賀聖一・大橋登美男：食品工誌, 24, 319(1977).

157）芳賀聖一・大橋登美男：食品工誌, 25, 226(1978).

158）芳賀聖一・大橋登美男：食品工誌, 25, 231(1978).

159) Fennema, O.: Food Proteins, (Avi Pub. Co.) p. 50 (1977).

160) Llewellyn, J.W. and Flaherty, B.: J. Food Technol., 11, 555 (1976).

161) Ford, J.R., Mustakas, G.C. and Schmutz, R. D.: J. Am. Oil Chem. Soc., 55, 371 (1978).

162) Richardson, F.M.: J. Assoc. Off. Anal. Chem., 61, 986 (1978).

163) Llewellyn, J.W., Dean, A.C., Sawyer, R., BAILEY, F.J. and HIтchсоск, C.H.S.: J. Food Technol., 13, 249 (1978).

164) Kitamura, K., Takagi, T. and Shibasaki, K.: Agric. Biol. Chem., 41, 833 (1977). 